\title{
Mixed Glioma
}

National Cancer Institute

\section{Source}

National Cancer Institute. Mixed Glioma. NCI Thesaurus. Code C3903.

A tumor composed of two or more glial cell types (astrocytes, ependymal cells, and oligodendrocytes). 